\title{
International Law is Western Made Global Law: The Perception of Third-World Category
}

\author{
Brian-Vincent Ikejiaku* \\ School of Law and Criminology, Derby University, Kedleston Road, Derby DE22 1GB, UK
}

\begin{abstract}
The way in which international law has been constructed and reconstructed over the ages in favour of the Western countries has driven some Third-World scholars to perceive international law as 'a global law made by the West' for the purpose of controlling global undertakings. In the past, international law was used by the Westerners to legitimise colonialism and all their acts of exploitation in the developing countries. In the modern period, international law is predominantly used to protect, project and promote $\left({ }_{3} \mathrm{Ps}\right)$ the interest of the Westerners. This includes their multinational businesses scattered globally, and protectionist bid against terrorist attacks. This paper uses theoretical, critical and multidisciplinary approaches to examine this perception of international law. It concludes that construction and reconstruction of international law in favour of Western countries has been one key instrument that perpetuate severe inequality between the Global North and Global South, which in turn hampers efforts toward global-peace and security.
\end{abstract}

\section{Keywords}

International law and development; Third World; inequality; Global North; Global South; global peace; global security; humanitarianism/human rights

\section{Introduction}

The term 'international law' was first introduced by Jeremy Bentham;' this term, which simply means the system of law that governs relations between States/

*) E-mail: B.Ikejiaku@derby.ac.uk. Dr. Brian-Vincent Ikejiaku is an international interdisciplinary scholar of International Law and International Relations; his research takes non-western perspective within the framework of international development. He was a Member of the Research Institute for Law, Politics and Justice, at Keele University, UK and formerly served as a lecturer in law at Madonna University, Nigeria. He has published widely from an interdisciplinary (IL and IR) context. His recent works (2010-2012) feature in JPL, IJDC and NJIL. Dr. Ikejiaku lectures Law at the British Institute of Technology and E-commerce (BITE) UK, and part-time at the University of Derby, Derby, UK. He visited as a Senior Lecturer overseas including serving as an interim Head of the Department of International Law Unit in the Madonna University Nigeria in the first quarter of 2012.

1) Whereas, Hugo Grotius (who traced the discipline of international law to Francisco de Victoria, a sixteenth Century Spanish Christian) is commonly regarded as the Father of international law - see A. Nussbaum, A Concise History of the Law of Nations (Macmillan, London, 1954); D. Kennedy, 'Primitive Legal Scholarship', 27 Harvard International Law Journal (1986), 1-13, both works cited in M. Mutua, What is TWAIL? (Lecture delivered to the American Society of International Law, 200o), Proceedings of the 94th 
nations has been given alternate names - law of nations, law among nations and inter-state law - this implies that State is seen as the only subject of international law. Though in the modern times, the reflection of international law clearly suggests that States are no longer taken as the sole actors of international law, since new actors have emerged in the international plane: public international organisations (IGOs), non-governmental organisations (NGOs), transnational corporations (TNCs) and private individuals (PIs). In spite of this development in relation to the increase in the number of the actors in international law, the Western developed countries have continued to construct and reconstruct the norms of international law in their favour to the detriment of the third-world countries. Thus, a group of scholars ${ }^{2}$ with the majority from the third-world countries have embarked on critical scholarships under the name, Third-World Approach to International Law (TWAIL), in order to address the injustices against the third world due to the hijacking of international law by the developed countries. It is in this context that Chimni points out, 'the dismal experience of the vast majority of third-world peoples and states in recasting colonial international law as universal international law in the last six decades has compelled a new generation of scholars to revisit the history of international law in a bid to find answers'. ${ }^{3}$

To a large extent now, some scholars (particularly from the Western world) have failed to see the rationale behind the argument or transforming international legal thought being put forward by the proponents of TWAIL. As Alvarez at the TWAIL conference in Paris suggests, this is telling:

The French and English international law academies had diverged with respect to the study of the Third World... Many of the commentators, particularly those based in Paris, were skeptical that TWAILERs had much to contribute either with respect to any 'rethinking' of the Third World

Annual Meeting: International Law in Ferment: A New Vision for Theory and Practice; April 5-8, 2000, Washington, DC. However, it was Jeremy Bentham who first introduced the term international law - see A. Hamid, Public International Law: A Practical Approach 2nd edition (Pearson, Prentice Hall, Kuala Lumpur, 2007).

2) See for example, R. Anand, International Law and Developing Countries: Confrontation or Cooperation: (Kluwer, Dordrecht, 1987); A. Anghie, Imperialism, Sovereignty and the Making of International Law. (Cambridge University Press, Cambridge, 2004); B.S. Chimni, 'International Institutions Today: An Imperial Global State in the Making', 15 European Journal of International Law (2004) 1-37; and B. Rajagopal, International Law from Below: Development, Social Movements and Third World Resistance. (Cambridge University Press, Cambridge, 2003).

3) B. Chimni, 'The Past, Present and Future of International Law: A Critical Third World Approach', 8 Melbourne Journal of International Law (2007), 499-515. Here Chimni employs the term "recolonisation" to encompass situations where construction and reconstruction of international law by Westerners is at the disadvantage of Third-world people: one - 'the reconstitution of the relationship between State and international law so as to undermine the autonomy of third-world States and to the disadvantage of its peoples; two - the expansion of international property rights which are to be enforced by third world States without possessing the authority to undertake the task of redistribution of incomes and resources; three - the relocation of sovereign economic powers in international trade and financial institutions; and four - the inability of third-world states to resist the overwhelming ideological and military dominance of the first world' (Ibid.). 
concerns or with respect to the larger humanistic program anticipated in the symposium program. The criticism of TWAIL by some of the European-based scholars fell into two strands. TWAILERs, it was suggested, brought nothing new to the table that had not been anticipated by others, including those closer to the 196os' struggles for decolonization and economic independence from the West. On the other hand, it was also suggested that TWAILERs' radical deconstruction of international law, like the crit movement of which it was part, was nihilistic, disinterested in the kinds of pragmatic reforms that remain relevant, and ill-suited to the needs of practice. ${ }^{4}$

This group of scholars is more familiar with, or show more interests in the common controversy concerning the history of international law bordering on whether international law is law or not and, about language ambiguity - that is, the argument that lack of a legislature and sanctions in international law led some nineteenth-century philosophers to deny that international law is actually law. And that the history of international law, just like the history of the Charter of the United Nations, has been a series of disputes about the correct interpretation. Language is inherently ambiguous, and there continuous to be dispute about the interpretation of rules of law which are expressed in words. One reason being that international law like the Charter at its inception was drafted mainly by politicians, with little assistance from lawyers. ${ }^{5}$

The international law argument perceived as TWAIL is diametrically different from the aforementioned position. TWAIL is conceived by third-world intellectuals out of the practical experience of the situations of inhabitants of the thirdworld countries because of the process and application of international law, and how it affects the third-world people. As Chimni suggests, this is a critical approach that gives meaning to international law, that transforms it into international law of emancipation; with the primary goal of shaping and reshaping international law as international legal norms that offer a life of dignity for the poor, deprived, oppressed and subjugated in the third world. ${ }^{6}$ This is an approach that provides very distinct meaning or interpretation to international law in a prevailing condition of the third-world people within the context of their experiences during the colonial and post-colonial period. This third-world approach to international law is precisely what this paper considers in its argument and analysis.

4) See J. Alvarez, My Summer Vacation (Part III): Revisiting TWAIL in Paris (2010), available online at http:// opinionjuris.org/2010/09/28/my-summer-vacation-part-iii-revisiting-twail-in-paris/ (accessed 22 April 2012). It is instructive to know that TWAILERs have provided us with five abiding insights: (i) that colonial patterns of thinking persist and continue to structure our international concepts; (ii) the 'civilizing mission' continues to drive, often to ill effect, current legal phenomena (from the turn to international organisations to concepts like 'good governance' and the responsibility to protect $\left(\mathrm{R}_{2} \mathrm{P}\right)$; (iii) that racism and misplaced notions of cultural superiority continue to obliterate the contributions of and concerns expressed by non-Europeans; (iv) that commercial/economic concerns, including Marxist notions of 'class', remain central to understanding our legal regimes; but that (v) contemporary forms of globalisation have rendered geographically based notion of 'imperialism' or 'hegemony' overly facile in understanding the Gramscian forms of collaboration that now characterise the 'Third World' itself (Ibid.).

5) M. Akehurst, A Modern Introduction to International Law (Allen and Unwin, London, 1970).

6) B. Chimni, supra note 3 . 


\section{International Law, Global North (the West) and Global South (the Third World): A Brief Insight}

Since the 18th century global events, as reflected by the application of international law in the context of the people of third-world countries, have been replete with accounts of dominations, manipulations and subjugation, schemed and master-minded by the Western world. International law has been constructed and reconstructed within this period to favour the Westerners or to protect their activities and undertakings in an unequal world. This is transparently reflected by the general equality-gap between the Global North and Global South. As Chimni's viewpoint may suggest, 'international law is playing a crucial role in helping legitimise and sustain the unequal structures and processes that manifest themselves in the growing north-south divide. Indeed, international law is the principal language in which domination is coming to be expressed in the era of globalisation'. ${ }^{7}$ International law from the early stage is a creation guiding the activities of the States of the North and the South that are unequal in all respect - political, economic and military, etc, and this has been a cause for challenge by the States of the South. The issue is not just that the Global North is more developed than the Global South, but also international law at its early stage was a complete contrivance of the former (Global North) and is bound by their biased interpretation; this is also telling, as it is clearly highlighted:

\footnotetext{
The new Asian and African States have less developed economies than their Western neighbours, and their populations have, therefore, a lower standard of living than the average for the States of Western Europe and North America. International law in its early stages was developed by States that had more or less similar standards of economic development, and that accepted the colonial principle. It has, therefore, been natural for some of the new States to challenge some rules of international law, just as much as the Latin-American States challenged some rules of international law at the Hague Conference of 1907, with the consequent contribution that those States had to make to the stability of the international order. There are several areas in which Asian-African' discontent has found special expression but on the whole the new States plead their causes by reference to international law, though naturally the reference is to their interpretation of it. ${ }^{8}$
}

In the past, international law was used by the Westerners to legitimise or justify all their acts of exploitation and subjugation in the developing countries; for example, it is documented that international law was used by the Westerners to justify slavery, colonialism and exploitation or to drain the resources of the areas, particularly Third-World countries subject to colonialism. Thus, Mutua is right to comment that 'the regime of international law is illegitimate. It is a predatory

\footnotetext{
7) B. Chimni, 'Third World Approaches to International Law: A Manifesto', 8 International Community Law Review (2006), 3-7, at 3 .

8) See I. Head, Contribution of International Law to Development. Paper presented at the Fifteenth Annual Conference Canadian Council on International Law, Ottawa (1986) 17 October, 5. Ivan Head was the President, International Development Research Centre to the Fifteenth Annual Conference.
} 
system that legitimizes, reproduces and sustains the plunder and subordination of the Third World by the West'. ${ }^{9}$ In the modern period, international law is predominantly used to protect, project, promote $\left({ }_{3} \mathrm{Ps}\right)$ or to safeguard the interest of the Westerners; for example their multinational businesses ${ }^{10}$ scattered all over the world and, as a protectionist edifice against terrorist attacks that not until recently are more directed to the Western countries.

This article examines the view by some scholars who perceive international law as a 'global law made by the West', by concentrating on two crucial issues: one, international law as an object used to nurture and maintain colonial and neocolonial domination of the countries of third world; and two, international law as an instrument for maintaining the austerity and economic conditions of underdevelopment of third-world countries through policies of international financial institutions that the West controls. This paper by concentrating on these two salient issues highlights various areas of international law ${ }^{11}$ in order to provide a general understanding of how its construction and reconstruction affect the thirdworld people.

\section{International Law as an Object used to Nurture and Maintain Colonial and Neo-Colonial Domination of the Third World}

\subsection{Definition of the Term 'Third World'}

It will make sense to start by defining what the term 'Third World' means. One, this refers to a group of countries with certain common features. Whereas, the developed capitalist countries constitute the first world, the socialist countries are called the second world. The underdeveloped countries in Africa, Asia and Latin American that were subjected to colonial domination are called the third world. Two, and alternately, the superpowers are categorised as the first world, other developed countries including United Kingdom, Germany, Australia and Canada

\footnotetext{
9) M. Mutua, supra note 1.

10) B. Ikejiaku, Ethical and Legal Aspects of CSR: issue of MNCs and sustainable development, (2012) Nordic Journal of Commercial Law, available online at http://www.njcl.utu.fi/1_2012/brian_vincent_ ikejiaku.pdf. The Western developed countries give protection to these multinational firms than the citizens of the third-world countries where they operate their businesses, including contributing poorly to their sustainable development. Jurisdictional and economic divides made it possible for giant MNCs to bargain for relaxed liability standards in return for foreign direct investment in developing and thirdworld economies.

11) This includes some accounts that border on: public international law, international economic law, international humanitarian/human rights law, international environmental law, and international law and development.
} 
are classified together as the second world. The third world consists of underdeveloped countries of Latin America, Africa and Asia. ${ }^{12}$

The two different meanings given above have a few things in common, the attributes of the third world are the same. The meaning of third world as given in both of the classifications is in relation to the developed countries. The thirdworld countries are economically poor (though it should be noted that some of the third-world countries, such as the states in the Arab Gulf, are rich) and they have a colonial past. While some of these countries operate with democratic institutions, others have been undemocratically ruled by military regimes. There are also differences that exist among the third-world countries in terms of social formations ranging from tribal societies to capitalist societies. In spite of these remarkable differences, the category 'third world' is not a meaningless one, since it helps in grouping together countries that came into being by fighting against the colonial domination. In fact, they all encounter similar problems because of their background. Thus, there are general characteristics that the States in the Third World have, which may largely be attributed to the fact that they have been colonised and that colonialism has introduced certain fundamental changes in their societies. $^{13}$

Mutua, in providing the meaning of Third World, captures the view of Julius Nyerere concerning the domineering and exploitative nature of international legal and economic order on the defenceless Third World:

The Third World consists of the victims and the powerless in the international economy.... Together we constitute a majority of the world's population, and possess the largest part of certain important raw materials, but we have no control and hardly in influence over the manner in which the nations of the world arrange their economic affairs. In international rule making, we are recipients and not participants. ${ }^{14}$

\subsection{International Law and Colonialism}

International law is the major legal edifice that has been used in nurturing and maintaining colonial and neo-colonial domination of the third world. This is in line with the view of scholars like Anghie that the rules of international law in important areas, such as laws relating to the acquisition of territory, recognition, state responsibility and state succession, were constructed to suit the indispensability of colonialism. ${ }^{15}$ With the domineering instrument of international law,

12) See for example, J. Manor, Returning Third World Politics (Longman, Oxford, 1991); and H. Galbowrne, Politics and State in the Third Word (Macmillan, London, 1979).

13) See Manor (1991) and Galbowrne (1979) (Ibid.).

14) See K. Nyerere, South-South Option, in The Third World Strategy: Economic and Political Cohesion in the South (Altaf Gauhared, 1983), pp. 9, 10, In Mutua (2000), supra note 1, at 35.

15) See A. Anghie, Imperialism, Sovereignty and the Making of International Law (Cambridge University Press, Cambridge, 2005). In this work Anghie indeed places the colonial project as the hub of international law; see also Chimni (2007), supra. 
the third-world people and their countries were compelled (without consent) to become the subject of international law. In this context, the third-world States as sovereign entities and virtually all the rights of the people in these States were surrendered to the colonial overlords. It is against this backdrop that recent postcolonial scholarships have emphasised the extent to which colonialism was not only a matter of sovereignty, but as well, that affecting the rights of the citizens. This is understandable when it is appreciated that the major import or raison d'etre of colonial governance was the racial and cultural incapacity of the colonised to govern themselves. Colonial rulers regarded native conditions as uncivilised and as requiring improvement, while forbidding citizenship and the attendant rights of self-improvement to colonial subjects. ${ }^{16}$

\subsection{International Law and Estrangement of the People of the Third World}

The kind of relationship that existed between the third-world people and international law (an edifice of the Westerners) is such that it is directly or indirectly concerned with the estrangement of international law from the people of third world, based on strings that strongly, but inextricably connect or bond them with the past, current and the future international law. The term estrangement here means a kind of alienated, but complex relationship that exists between the individuals, society and nature of international law under global capitalism; and the slow transformation of international law into internal law. ${ }^{17}$ This isolation of the people of third world from international law manifests on the relegated place assigned to third-world people in the history of international law. This is because during the early stage of international law, they were seen as backward, crude, barbaric and uncivilised, and therefore incapable of participating in the international legal order. For example, argument is put forward that African states lacked the power to sign legal treaties to transfer their sovereignty to a European power. ${ }^{18}$ The beginning and the emergence of a Global State, was marked through greater application of cleverness and subtleness in the use of international law to secure the interest of the powerful Westerners than in the past when legitimacy is derived by the employment of force.

The colonial period is a clear demonstration of how the notions of justice from the context of international law has been subverted in order to ensure not only the appropriation of the rights of the people of the third world, but as well, the enslavement of the larger part of humanity and the use of division to maintain control of the colonies.

In some parts of the third-world colonies, the colonialists employed the policies of divide and rule to co-opt, but this system of indirect rule destabilised the

\footnotetext{
16) See P. Chatterjee, The Nation and its Fragmentation (Princeton University Press, Princeton, NJ, 1993).

17) Chimni (2007), supra.

18) See J. Gathii, 'International Law and Eurocentricity', g European Journal of International Law (1996), $184-211$.
} 
third-world nations. ${ }^{19}$ The colonial rule did not promote the values necessitating good governance in third-world countries, despite the fact that the main colonial powers in third-world colonies were themselves democratic countries. In the first place, the institutions they created were apparatuses of domination. By control over vast areas with distinct populations, they stressed functional utility, law and order, but not participation and reciprocity. Also access to the colonial order was generally blocked and distanced from the scrutiny or inspection of the people it claimed or purported to govern. There was a remote, bureaucratic and patrimonial form of politics which flourished under a state that violated as a matter of practice or routine the domestic legal norms, the values of democratic tenets and the normative facet of governance. ${ }^{20}$

\subsection{International Law and the Mandate System}

The mandate system that existed during the colonial rule was a subtle application of the international law of acquisition that gave authority to colonial masters to take control of the administration of the colonies. It is a calculated method to maintain the prolongation of European rule of subjugation over the people of third world. The Mandate form of rule, which Sornarajah describes as "the sacred trust of humanity" is a technique for justifying the continuation of European rule over other people. ${ }^{21}$

Extension of the 'Mandate of Sacred Trust' or 'Sacred Trust of Civilisation' shows how the Westerners contradict the norms and principles of international law, such as the Principles of Free Choice of Economic System (i.e., the right of every State to freely choose its economic system) in their deliberate attempt to constructing and reconstructing international law in their favour. This right of States to freely choose its economic system, which introduced the Declaration of Principles of International Law concerning friendly relations and cooperation among States as a component of sovereign equality; has been reiterated restated and, further elaborated in several important international legal instruments. For example, the Charter of Economic Rights and Duties of States (General Assembly Resolution 3281 (XXIX) 1974), in its Article 1 provides inter alia:

\footnotetext{
19) See F. Adigwe, Essentials of government for West Africa (Ibadan University Press, Ibadan, 1985). The negative effect of indirect rule in most parts of West Africa is well documented, see B. Nwankwo (1992); Odediran et al. (1990).

20) See K. Soremekun, The International Dimensions of Governance, in G. Hyden, W. Hastings, O. OkothOgendo and B. Olowu (eds.), African Perspective on Governance (Africa World Press, Trenton, NJ, 2000), 267-293.

21) M. Sornarajah, Power and Justice: Third World Resistance in International Law (Singapore Year Book of International Law, Singapore, 2006), 19-57.
} 
Every State has the sovereign and inalienable right to choose its economic system, as well as its political, social and cultural systems in accordance with the will of its people, without outside interference, coercion or threat in any form whatsoever. ${ }^{22}$

However, for centuries, beginning with the slave trade, the West continuously has ruthlessly exploited the third-world people. The turning of most of third world into a commercial warren for the hunting of black skins was one of the chief sources of 'primitive accumulation' that signalled the rosy dawn of the era of capitalist production. Sadly, the abduction and enslavement of millions of Africans was only the start because in the late nineteenth century, in what became known as the 'scramble for the colonies' especially Africa, was arbitrarily carved up into colonies by the leading European powers. They then violently subjugated its people and plundered the continent of its rich natural resources. In the postindependence eras, third world states became weak pawns in the world economy, their path to development largely blocked by their weakening past colonial legacies. ${ }^{23}$ Thus, the continuous manipulations of virtually all aspects of the principles of State sovereignty through the dogmatic instrumentalism of international law under the machinations of the Global North and the international institutions (they dictate), show that international law from ab initio is nothing, but a global law made by the Westerners in order to control the third world.

\section{The Use of International Law Through the Policies and Actions of International Financial Institutions to Control Economic Relations with Third World}

\subsection{International Law and Economic Liberalisation of the Third World}

There has never been a time when economic progress in the third-world countries through the much popular international economic liberal movement has been taken seriously; rather international economic law regime is control by the Western countries through international financial institutions, which initiate and implement policies and actions that continue to foster underdevelopment the third world. Since the third world States were assumed not to have personality in international law, their interest have from the get go continued to suffer because they did not have a role to play in shaping the norms of the earlier international legal order. This, to a great extent, has influenced the present international legal order, particularly in the realm of economic liberalisation of the third world states. In this context, international law has been used to construct and reconstruct the

22) M. Bedjaoui, International Law: Achievements and Prospects (UNESCO, London and Martinus Nijhoff, Boston, MA, 1991), 599 .

23) See J. Wiseman, Political Leaders in Black Africa (Edward Elgar, Williston, VT, 1991). 
meaning of sovereign States by re-allocating the hitherto sovereign economic powers of the third world States to international financial institutions. This to a large extent limits the possibilities of third world States to pursue independent, meaningful and self-reliant development. ${ }^{24}$ As Sornarajah argues, 'the espousal of economic liberalism by the World Bank, the IMF and the WTO ensure that these institutions will not favour collective rights such as the right to development'. ${ }^{25}$

The international economic liberalism is one of the major powerful tools of international economic law agenda pursued by the Westerners through the auspices of the international financial institutions, in order to continue maintaining the subjugation and control of the third-world countries. The Western justification for the international democratic and economic liberalisation agenda is that it will help: to reduce the resource gap in the Less Developed Countries (LDCs) of the third world, by improving the trade balance and encouraging a net capital inflow, ${ }^{26}$ and to eradicate poverty and improve economic development of underdeveloped states. ${ }^{27}$ Thus, the growing importance of international organisations such as the $\mathrm{G}_{7}$, IMF and World Bank is indicative of the influence of liberal economic internationalism in the post-Cold War period. ${ }^{28}$ Hence, the granting of aid and loan to the poorer communities, as a means for the elimination of hunger and disease in the Third World become the primary aim which these institutions based their activities.

However, the argument has been put-forward that, events in the developing world provide us with some critical reasons why attempts made in redressing the situation (of transparent inequality between the Westerners and Third World as a result of exploitations and injustices by the later) through the encouragement of increased foreign borrowing have contributed to the problem of debt crisis in the third world by increasing the resource gap even further. ${ }^{29}$

These powerful transnational bodies which embody free trade liberalism as their governing ideology, however, impose free market strictures on developing societies. Since they are the primary organisations which formalise and institutionalise market relationships, including the international legal norms guiding States; they lock peripheral states into involuntary agreements which force them to lower their protective barriers (GATT and NAFTA for instance), thereby

\footnotetext{
24) Chimni (2006), supra note 1.

25) Sornarajah (2006), supra note 40.

26) T. Biersteker, Dealing with Debt: International Financial Negotiation and Adjustment Bargaining (Westview Press, Oxford, 1993).

27) Sornarajah (2006), supra note 40.

28) Biersteker (1993), supra note 26.

29) See B. Ikejiaku, 'Africa Debt Crisis and IMF, with a Case of Nigeria: Towards Theoretical Explanations', 1 Canadian Journal of Politics and Law (2008), 2-7.
} 
preventing third world nations from developing trade profiles which diverge from the model dictated by their supposed 'comparative advantage'. ${ }^{30}$

Good evidence is the nature of obligation accorded to the adoption of the agreements comprising the Final Act of the Uruguay Round of Trade Negotiations that lacked transparency. There is a clear suggestion that third-world countries gained little from the Uruguay Round agreements. ${ }^{31}$ The IMF and the World Bank make the provision of finance (or more accurately 'debt') to third world developing societies conditional on their unilateral acceptance of free market rules for their economies, the conditionality of the so called-structural adjustment programme 'SAP' in many third-world countries. ${ }^{32}$ For example, in Africa, SAP failed the majority of Nigeria; particularly it brought mass unemployment. ${ }^{33}$ Kenya also continues to express its displeasure at the IMF and the World Bank for forcing these policy changes on it. ${ }^{34}$ In the early 1980 , Uganda was rocked by weeks of demonstrations, as industrial workers and students took to the streets to denounce President Miton Obote's IMF-imposed economic programme and in 1990, Matthew Kerokou of the Benin Republic in West Africa was removed from power following a wave of anti-SAP riots. ${ }^{35}$

It is therefore not surprising that notable scholars, such as Sachs, criticize the IMF and World Bank for imposing draconian budgets to support SAP. In his view, the approach had 'little scientific merit and produced even fewer results' ${ }^{36}$ It could rightly be argued that it is no coincidence that the governments that continued to operate quite well (e.g. Botswana) never had to subject themselves to the painful cure of SAP. ${ }^{37}$ The poor countries are, therefore, constantly de-capitalised and their economies remain largely upon decision made by Westerners in New York, London, Paris and other metropolitan centres, and implemented through the international institutions they dictate. ${ }^{38}$ As Chimni has submitted, 'the economic and political independence of the third world is being undermined by policies and laws dictated by the first world and the international institutions it controls'. ${ }^{39}$

30) S. Burchill, A. Linklater, R. Devetak, J. Donnelly, T. Nardin, M. Paterson, C. Reus-Smit and J. True, Theories of International Relations (Macmillan, London, 1996).

31) Chimni (2006), supra note 1.

32) See B. Onimode, The IMF, the World Bank and the African Debt, the Economic Impact (Zed Books, London, 1989).

33) African Forum on Network and Development, Nigeria: Foreign Debts Stolen Wealth, IFIs and The West, A Case Study (AFRODAD, 2007).

34) P. Wayande, State Driven Conflict in the Horn of Africa (USAID, 1997).

35) S. Dare, 'A Continent in Crisis, Africa and Globalisation', Dollars and Sense Magazine (July/August 2001).

36) J. Sachs, The End of Poverty: How can we make it happen in our life (Penguin, London, 2005), 198.

37) Hyden et al. (2000), supra note 17.

38) K. Hosti, International Politics: A Framework for analysis (Princeton International, Princeton, NJ, 1995).

39) Chimni (2006) supra note 1 , at 3 . 
The activities of these financial institutions guided by the norms of international economic law were more or less to maintain the nature of neo-colonialism in the third-world countries. ${ }^{40}$ This contention becomes glaring when it is appreciated that the IMF was initially a pure European establishment. During the first period of its existence, the IMF gave the impression of certain efficiency as it helped to re-establish the convertibility of European Currencies (1948-1957); then helped European economies adjust (1958-1966). From 1967 onwards, however, the fund failed to maintain stability despite the creation of Special Drawing Rights (SDRS); parity adjustments were numerous after this date: devaluation of the Pound and the Franc, revaluation of the German Mark and the Japanese Yen, floating of the price of gold, etc. The adoption of the General system of floating currencies in 1973 may be considered to have marked the end of the Breton Wood's mandate. At a point, the continued existence of the IMF was called into question. The institution survived by taking new functions: Management of unilateral structural adjustment in developing countries of the third world, and, from the end of the 1980 s, intervention in many third-world countries with the goal of ensuring the reincorporation of these countries into the international monetary system. ${ }^{41}$

Imperatively, and drawing from the above revelations, one might be tempted to ask why an institution (IMF) which once failed to deliver in Europe was drafted to take the lead in the economic recovery of Africa and other developing world. Surprisingly, and as if oblivious of the question of incompetence on the part of the IMF, the Western governments moved to implement the recommendations of the institution by granting of loans/aids to any third-world countries that follow the IMF's economic liberalization policies.

International Development Forum informs us that the annual expenditure on health in the poorest countries average less than $\$ 5$ per person. In wealthier countries such as USA, Canada, etc. health expenditure average $\$ 400$ per person. ${ }^{42}$ This is because the poor are either entirely unemployed or underemployed. The situation is contrary to the decades before economic reforms were introduced, and as the 1997 IMF Report has confirmed. According to it, in the decade prior to 1985, many third-world countries in East Asia, South Asia and sub-Saharan Africa experienced annual growth rates of employment in excess of 5 percent with some as high as 10 percent per annum. ${ }^{43}$ Again, the loans and aid administration from the developed to underdeveloped third world States remain economically retrospective. In this perspective, it can be pointedly contended that, one of the biggest stumbling blocks to third world development in modern times was the external debt crisis that accrue as a result of the manipulation of the global economic

40) Okafor, C. Neo-Democracy and Poverty Management in Africa (Awka: Mercury Bright Press, 2004).

41) S. Amin, 'Fifty Years is Enough (Part 1)', 46 Monthly Review (1995), 8-50.

42) B. Onimode, The IMF, the World Bank and the African Debt, The Economic Impact (Zed Books, London, 1989).

43) Ibid. 
system by the international financial institutions. This is clear in a forward on Anighie's work:

\begin{abstract}
The newly independent states... fought to develop new rules, even a new international economic order. But in the event the Bretton Woods Institutions triumphed, imposing their own view of development and a certain set of structures of governance on half the world's population and a majority of its governments. The outcome has been, on the whole, increased indebtedness and new forms of dependence. ${ }^{44}$
\end{abstract}

\title{
4.2. International Environmental Law and Exploitation of the Third World
}

The international environmental law has done little in the protection of the thirdworld people, in relation to the exploitative activities being perpetrated by Multinational Corporations. International environmental law as part of the construct of the Westerners rather is today subordinated to corporate powers, which dictate both the dwindling economic consumption patterns and environmental depletion in the third world States as against the high consumption patterns and environmental protection in the rich countries. For example, in the Democratic Republic of Congo (DRC), Anglo American Gold, a US company has allegedly continued illegal exploitations and consequential environmental hazards. Also recently, the US companies including IBM, Intel, Motorola, Apple and Hewlett-Packard were asked to disclose whether they use DRC's minerals and other resources being (illegally) exploited to supply multinationals in their need of raw materials, particularly in Rwanda, Uganda and Burundi. ${ }^{45}$ It is in this context that the Catholic Agency for Overseas Development (CAFOD), in reaction to the exploitative activities of some multinational companies (and the suffering of the people of DRC and other third world States) calls both the international community, and national government of resource-rich third-world countries - 'to ensure that there is a balanced legal framework in place that recognises the interests of the broader population ... 46

The Niger Delta is another good case study. Niger Delta's potential for sustainable development remains unfulfilled, and is now increasingly threatened by environmental devastation and worsening economic conditions. In spite of the enormous wealth accrued from their land by oil companies, the people continue to live in unfavourable conditions without electricity, pipe borne water,

\footnotetext{
44) See Forward by James Crawford of the Lauterpacht Centre for International Law Cambridge University, on Antony Anighie's book, Imperialism, Sovereignty and the Making of International Law (Cambridge University Press, Cambridge, 2004).

45) See Ending illegal exploitation of Democratic Republic of Congo Mineral and other Resources, available online at http://therisingcontinent.worldpress.com/2010/11/24/ending-illegal-exploitation-of-democraticrepublic-of-congo-minerals-and-other-resources/ (accessed 11 January 2011).

46) See Catholic Agency for Overseas Development, Unearth Justice (CAFOD Report May, 2006) 12.
} 
hospitals, housing and schools. ${ }^{47}$ The Ecumenical Council for Corporate Responsibility (ECCR) considers how the operations of Shell's Nigerian subsidiary, the Shell Petroleum Development Company (SPDC), affect the human rights and living conditions of Niger Delta communities. Based on case studies researched and written by five civil society organisations working in the Niger Delta, there are concerns about Shell's operations in relation to international social and environmental standards, pollution levels, communities' health and livelihoods, and the right of local people to a say in decisions that affect their lives. ${ }^{48}$ Human rights and corporate responsibility advocates concur that activities of Shell negate the provisions in the International Covenant on Civil and Political Rights and the Covenant on the Economic, Social and Cultural Rights of the United Nations, both of which Nigeria is a signatory. 49

The case is not the same in the rich countries where international environmental law works effectively to protect the people. For example, the environmental pollution of Oil-spill in the Deepwater Horizon of the Gulf of Mexico, which killed 11 workers because of the oil-pipe line spill of the Shell British Petroleum (the same oil company that has been doing environmental havoc and killing hundreds of people in the third-world countries) made headlines around the world, since it is described as the worst environmental disaster in US history. ${ }^{50}$ The US even went ahead to sue the Shell B.P. and eight other subsidiaries alleging that the cause of the 20 April oil explosion in the US was due to violations of safety and operational regulations. ${ }^{51}$ This is one of such cases where national environmental law is effectively working and protecting the people in the Western countries. It provides a good illustration as to the use of such norms which have crept into international environmental law, as perceived by the third world, is nothing but a global law made by the Westerners for the purpose of directing and controlling

47) See A. Onduku, Environmental Conflicts: The Case of the Niger Delta; A Paper presented at the One World Fortnight Programme Organised by Department of Peace Studies, University of Bradford, Bradford, UK, November 2001. The late environmentalist and minority rights crusader, Ken Saro-Wiwa summed it up by describing the pitiable situation of his 500 ooo Ogoni people in the Niger Delta to have been relegated to slavery and extinction.

48) See The Ecumenical Council for Corporate Responsibility Shell in the Niger Delta: A Framework for Change (2010), available online at http://sndden.wordpress.com/2010/03/23/shell-can-improve-impactsin-the-niger-delta-says-new-report/ (accessed 11 January 2011).

49) For example, see ECCR Report (2009), supra.

50) See Nigeria's Agony Dwarfs the Gulf oil spill. The US and Europe ignore it, available online at http://m .guardian.co.uk/world $/ 2010 / \mathrm{may} / 30 /$ oil-spills-nigeria-niger-delta-shell? cat=worlds\&type=article (accessed 11 January 2011).

51) See BBC News US and Canada, Gulf of Mexico oil leak: US sues BP over oil disaster, available online at http://www.bbc.co.uk/news/world-us-canada-12005240 (accessed 11 January 2011). The companies involved in the joint suit include - BP Exploration and Production Inc, Anadarko Exploration \& Production LP, Andarko Petroleum Corporation, Transocean Holding LLC, Transocean Offshore Deepwater Drilling Inc, Transocean Deepwater Inc, MOEX Offshore 2007 LLC, Triton Asset Leasing GMBH and insurer QBE Underwriting Ltd/Lloyd's Syndicate 1036. 
global undertakings. ${ }^{52}$ International law merely exists in principles in the thirdworld countries and therefore provides little or no protection to human rights (political, economic, social and cultural) of the people, while in the Western countries international law apparently effectively works to protect the human rights of the people. Mutua in this perspective reaffirms that 'the international human rights regime is merely a Western contrivance, a new form of imperialism - this time of a moral dimension - used to export a cultural package of the West'53

\subsection{International Development Law and Third World}

Law and development provides another crucial aspect of international law that has been used by the Westerners, and that is being implemented by the international institutions to continue to maintain the domination and estrangement of the third-world people. The law and development movement started in the 196os to reform the judicial systems and existing laws of countries in third world (Asia, Africa and Latin America). However, within a short period of its inception, both the academic participants ${ }^{54}$ and the then Ford Foundation officer heading the project $^{55}$ acknowledged the law and development regime as a failure. One strong

52) This is an oil spill disaster where the oil company or companies are being held responsible for government removal costs, economic loses, and environmental damages, among others without any limitation. Compare this with the pathetic situations caused by the activities of MNCs in the third-world countries. DRC offers one good instructive example - a country since the end of Mobutu's era in 1997 has been describes as a scene of organised looting of a sovereign State not seen in any part of the globe in recent times. Every type of wealth in the country has been impacted upon by structures set up and imposed by power from above. Stockpile of extracted minerals (coltan, gold, diamond, cassiterite, etc.) were seized and taken away as loots to Rwanda, Uganda and Burundi. There is indication that these minerals are exploited to supply multinationals in their need of raw materials - that has incited call for a world-wide campaign to boycott end products (laptops, cell phones, jewels, etc.) made from these minerals. The situation is such that for nearly two decades UN institutions and international justice system are being used or manipulated by Western powers because of their selfish polices and interest - see Ending illegal exploitation of Democratic Republic of Congo Mineral and other Resources, see note 32, op cit. Illegal exploitation by foreign MNCs here, is prohibited by the 'Protocol Against the Illegal Exploitation of Natural Resources (PAIENR) that was agreed on 30 November 2006, which reaffirms 'the Dar-es-Salaam Declaration on Peace, Security, Democracy and Development in the Great Lakes Region of 20 November 2004 and the fundamental principles enshrined in the 'United Nations Charter' and the 'Constitutive Act of the African Union'. Particularly Article 4 (Infringement of the Right of Permanent Sovereignty of States over Natural Resources) of the protocol provides inter alia: 'The illegal exploitation of natural resources shall be considered as violation of the right of Member States to permanent Sovereignty over their natural resources, and contrary to the spirit and principles of the United Nations Charter, the Declaration on the Right to Development adopted by the United Nations General Assembly, the Constitutive Act of the African Union and the African Charter on Human and Peoples' Rights'.

53) M. Mutua, 'Savages, Victims and, Saviors: The Metaphor of Human Rights', 42 Harvard International Law Journal (2001), 201-209.

54) See, for example, J. Merryman, 'Comparative Law and Social Change: On the Origin Style, Decline and Revival of Law and Development Movement', 25 The American Journal of Comparative Law (1977), 475-483.

55) See J. Gardner, Legal Imperialism: American Lawyers and Foreign Aid in Latin America (University of Wisconsin Press, Madison, WI, 1980). 
reason adduced by international development legal pundits for the failure of the law and development movement is that the norms of international law as packaged in the Western rich countries are in most cases in disharmony with the interests of the third world, most of which are poor developing countries. This forms the point of concern or reprimand by Head,

I simply caution that some of the applications of legal principles, designed as they often were in the industrialized countries, are not always equitable to the interests of the developing countries. It should not be surprising that the goals of the developing countries, newly independent as many of them are, are not identical to those of the industrialized countries, colonial powers as many of them were. ${ }^{56}$

Another primary reason which scholars have not put into consideration for the woeful failure of (international) law and development movement at its inception is that the package or the programme included no development scholar, expertise nor professionals from the third world; rather as a complete package of the West, it was executed only by the Western scholars and agencies. ${ }^{57}$ Currently law and development, both as a movement and practice have been facing serious challenges because, there is no agreement or uniformity between the development goals as projected by the leaders of third-world countries and those of the Western developed countries. More so, the Westerners have through the International Financial Institutions (IFIs) and other international institutions that they control, continued to harness international development affairs in ways that contradict the development and other domestic interests of the third world. Their approach to international law and development in the third world is more or less based on the situations or experience in the Western and developed world, which is either distinct from those of the third world or 'chews more than it can swallow' by attempting to fulfill too many broad-range of development goals. As Head asserts,

The development goals of political leaders North and South have proved in the short period Since World War II often to be widely divergent. Development, in the sense that dominates discussions at UNCTAD or the World Bank or OECD, consists of a number of dimensions of which the economic, sadly, has too often, in too many fora, been non-uniformly defined. When that happens, one of two

56) See I. Head, Contribution of International Law to Development. Paper presented at the Fifteenth Annual Conference Canadian Council on International Law, Ottawa, 17 October 1986, supra, p. 4.

57) The law and development movement was an ambitious project initiated by the US Agency for International Development, the Ford Foundation, and other private American donors, in an effort to reform the judicial systems and substantive laws of countries in Asia, Africa, and Latin America. The movement engaged professors from Harvard, Yale, Stanford, Wisconsin, and other leading American law schools (without involving any scholar, expert or professional from the third world - Asia, Africa and Latin America that project is targeted to develop). In spite of the fact that within a few years the project generated hundreds of reports on the contribution of law reform to economic development, yet both the academic and Ford Foundation professional official that partake in the project declared it a failure; see Law and Development Movement, available online at http://www.worldbank.org.INT. 
quite distinct processes ensues. Either development efforts endeavour to satisfy an impossibly wide range of goals and constituencies, or they become so narrow and tightly focused as to diminish greatly any likelihood of their harmonious inter-action with other events. ${ }^{58}$

Though scholars, particularly those from the Western world argue that the inability of international development to salvage the third-world countries is not based on master-minded scheming of the Westerners and the international institutions. Neocosmos for example argue, 'the failure of development to emancipate the people of Africa was not the result of a betrayal or a con trick, it was rather the effect of a hegemonic worldwide conception in the twentieth century, a view according to which human emancipation could only be achieved through one form or other state of politics'. ${ }^{59}$ However, there are good reasons why failure to salvage third world out of their development backwardness should be seen as a deliberate manipulation by the West. One of such reasons is the approach to international security and humanitarian regime (security being an aspect of international development). International security regime, shows gaps between a more developed and prosperous Global North as opposed to miserable realities of violent conflict and chronic poverty experienced by a significant proportion of the world's population, particularly those of the third world. These gaps and inequality, which not only reflect failures - of understanding, conflicts of interest, resource constraints and poor implementation; but also - a collaborative kind of plot with a high degree of subtleness between the Westerners and the international institutions against the third world. It is in this line that Luckham reasons, Security, (like development), is all too often seen as something the North delivers through its policy interventions and aid programmes, rather than as the product of obtaining positive changes in the developing South. ${ }^{60}$ This agrees with the views of some TWAIL scholars that the international security legal order has been constructed by the developed states of the North at the detriment of those of developing South. ${ }^{61}$

The welfare and development of the third world is in principle the primary concern or priority in the international development project, but practically, this is

58) See Head (1986), supra, p. 8.

59) M. Neocosmos, Development, Social Citizenship and Human Rights: re-thinking the political core of an emancipatory project in Africa (ICES Occasional Paper, Colombo, 2007) 3.

60) R. Luckham, Transforming Security and Development in an Unequal World, Institute of Development Studies (IDS) Bulletin Volume 40 Number 2 (Blackwell, Oxford, 2009).

61) For, example, see the works of scholars such as J. Gathii, 'International Law and Eurocentricity', 9 European Journal of International Law (1998), 184-211; A. Anghie, 'Colonialism, Environmental Damage and the Nauru Case', 34 Harvard International Law Journal (1993), 445-506; A. Anghie, B. Chimni, K. Mickelson and O. Okafor (eds.), The Third World and International Order (Martinus Nijhoff, The Hague, 2003); R. Anand, International Law and Developing Countries: Confrontation or Cooperation: (Kluwer, Dordrecht, 1987); A. Anghie, Imperialism, Sovereignty and the Making of International Law (Cambridge University Press, Cambridge, 2004); B. Chimni, 'International Institutions Today: An Imperial Global State in the Making', 15 European Journal of International Law (2004), 1-37; B. Rajagopal, International Law from Below: Development, Social Movements and Third World Resistance (Cambridge University Press, Cambridge, 2003) and other relevant works. 
not in the priority zone. According to Christian Aid, about 1 billion dollars that supposedly went to development aid were diverted from the war on poverty, and was instead channelled towards the war on terrorism. The US Congress reduced its aid package to development from 1.6 billion to 650 million globally. The United Kingdom redirected 150 million pounds of British development aid to the rebuilding of Iraq. The UK also pledged to provide $£ 600$ ooo to remove the minefields that were scattered by Gaddafi loyalists for the purposes of protection, and $£ 60$ ooo for security purposes. ${ }^{62}$ This is money that would have been provided for sustainable development project in Africa. Additionally, SIPRI statistics show that in 2001, the combined military spending of OECD countries was ten times higher than their combined levels of official development assistance. ${ }^{63}$ It is very conspicuous now that the West has decided to concentrate and invest more heavily on military, rather than on social and economic development, which is wrongly understood as a way to reduce poverty and underdevelopment. It is ultimately perceived as a better means to reduce the global threat to peace, security and stability. In other words, the route or option taken to invest 'more heavily' on militarisation instead on socio-economic development is making things more difficult globally, including the efforts towards global peace and security. ${ }^{64}$ McCormack argues in this perspective 'the level of material and strategic engagement with the developing world has fallen since the end of the Cold War (this has worsened post-9/11). The broader intervention context is one in which the developing world is less of a security concern to the developed than was the case during the cold war'. ${ }^{65}$ This equally forms the note of caution in the study carried by the NSI:

Lack of development in the poor countries, and unbalanced development in the middle - or high income countries, is often manifested in the violation of basic human rights, political and social

62) See A. Bloxham, Libya: What is David Cameron's Game-plan? (The Telegraph, 2011), available online at http://www.telegraph.co.uk/news/worldnews/africaandindianocean/libya/8764801/Libya-What-isDavid-Camerons-gameplan.html (accessed 17 October 2011).

63) See the view of S. Tadjbakhsh in the presentation of the 2005 Human Security Report: War and Peace in the 21st Century - Human Security Centre, The University of British Columbia, available online at http:// www.peacecenter.sciences-po.fr/conflicts-ip-st.htm (accessed 12 January 2011).

64) Scholars argue that while underdevelopment is not a direct cause of conflict as such, it is clear stated that poor social, economic and environmental conditions as well as weak or ineffective political institutions diminish a society's capacity to manage social tension in a non-violent manner - see S. Tadjbakhsh, Security and Conflict: Implications for Evaluation (IDEAS Conference, April 2005). Poverty is seen as being a cause of conflict, when grievances are not met, the poor and deprived in the society will riot, question the leadership as well and even join rebel groups. Deteriorating economic development and extreme poverty may then strengthen tendencies to resort to violent means or activities - see S. Verstegen, Poverty and Conflict: An Entitlement Perspective. Conflict Prevention Network (CPN). Briefing Paper : (Institute of International Relations, The Hague, 2001). Aside from the direct link between poverty, inequality and wellbeing, high levels of economic inequality can also indirectly undermine the ability of a society to promote valued capabilities. Inequality can be a source of social tension and violence - see J. Dreze and A. Sen, India: Economic Development and Social Opportunity (Oxford University Press, Delhi, 1995).

65) T. McCormack, 'Human Security and the Separation of Security and Development', 11 Conflict, Security and Development (May 2011), 235-260. 
repression, as well as widespread economic deprivation. Moreover, inadequate or unbalanced development is a threat not only to the security of individuals, but increasingly to local and international peace as well. ${ }^{66}$

\section{Suggestions}

This paper's argument has been thus: When international law was initially drafted, it was developed only by the Western countries. Though this paper acknowledges that certain reviews and changes have been made in order to reflect the changes in the global events that affect the development of international law and the dynamism of the international system. It is suggested that international conventions need to be conveyed in different continents around the globe. There should be two representatives (political and legal experts) from each State in the globe (as major actor) in the international law. In these conventions international law should be re-drafted to reflect the legal and political voices of the States in the international system.

It is the opinion of this author that a birth of a new international law that emerges from these global conventions with full representatives and participation from the big, small, rich and poor countries will be a key way to reduce global tension, and to achieving global peace and security. As (founding fathers) of each State and continent will understand and accept the weight of international law, and can rightly say to themselves and tell their future generations - 'yes, it is our international law, we participated in drafting it', rather than presently conceived by the third word category as 'a global law made by the Westerners'.

\section{Conclusion}

This paper, while adopting the Third World Approach to International Law, has assessed the general claim that international law is 'a global law made by the Westerners' for the purpose of directing and controlling global undertakings. This paper has suggested as follows: that international law is an object used to nurture and maintain colonial and neo-colonial inequality and domination of the third world. By the instrumentality of international law, the Westerners were able to compel the third-world people and their countries, without obtaining their consent to become the subject of international law. In this connection, the States as sovereign entity and virtually all the rights of the people in these states were surrendered to the colonial overlords. The colonial period demonstrates how the notions of equality and justice from the context of international law became

66) North South Institute, Human Security, Sustainable and Equitable Development: Foundation for Canada's International Policy (NSI Paper on the International Policy Review, Ottawa, ON, 2005). 
subverted in order to ensure not only the appropriation of the rights of the people of the third world, but as well the enslavement of the larger part of humanity and the use of division to maintain control of the colonies.

This paper also finds that the Westerners use international law to control economic relations with third world through the policies and actions of international financial institutions they dictate. This was seen through how poor countries are constantly de-capitalised and their economies remain hugely dependent upon decisions made by Westerners in New York, London, Paris and other metropolitan centres, and being implemented through the international institutions. The article also finds that law and development both as a movement and practice has been facing serious challenges because of pronounced inequality and no uniformity between the development goals as projected by the leaders of Global South and those of the Global North.

The claim of this paper is that all these issues emanate from the manipulation of the international law by the West, and concludes that this is the key instrument that perpetuates severe inequality between the global-North and global-South. This in turn hampers efforts toward global peace and security. The paper calls for a complete re-drafting of international law which States in the global south will participate. 